\title{
Nutritional status, family income and early breastfeeding initiation as determinants to successful exclusive breastfeeding
}

\author{
Dian Shofiya, ${ }^{1}$ Sri Sumarmi, ${ }^{2}$ Faruk Ahmed ${ }^{3}$ \\ ${ }^{1}$ Doctoral Program of Public Health, Faculty of Public Health; ${ }^{2}$ Department of Nutrition, Faculty of Public \\ Health, Universitas Airlangga, Mulyorejo, Surabaya Indonesia; ${ }^{3}$ School of Medicine, Griffith University, Gold \\ Coast, Australia
}

\begin{abstract}
Background: The target by the Indonesian public health services to obtain at least $50 \%$ exclusively breastfeed babies during the first 6 months has not been achieved, due to the increased in infant morbidity. This study aims to determine factors associated with exclusive breastfeeding.

Design and Methods: The cluster random sampling method was used to obtain data from a total of 273 babies in the first 1000 days of life i.e. aged 6-24 months and analyzed using linear regression at $\alpha=0.05$. The data obtained were based on exclusive breastfeeding using maternal age, education, family income, frequency of antenatal care, nutritional status before pregnancy, place and mode of delivery, gestational age at delivery.

Results: The result showed that exclusive breastfeeding was significantly affected by nutritional status before pregnancy based on MUAC $(\mathrm{P}=0.15)$ and BMI $(\mathrm{P}=0.047)$, family income $(\mathrm{P}=0.047)$ and initiation of early breastfeeding $(\mathrm{P}=0.001)$.

Conclusions: In conclusion, nutritional status before pregnancy tends to benefit the family income, therefore, initiating early breastfeeding need to be improved for successful exclusive breastfeeding.
\end{abstract}

\section{Introduction}

Exclusive breastfeeding is the act of administering only breast milk to a baby during the first 6 months of life (as well as supplements such as vitamins, minerals and medicines). According to the Ministry of Health Strategic Plan 2015-2019, the target for exclusive breastfeeding was $44 \%$ by 2019 , which has never been achieved. ${ }^{1}$ The low adoption of exclusive breastfeeding tends to affect the incidence of illness in infants. However, when properly administered, it reduces morbidity and death from diarrhoea and pneumonia. $^{2}$ In addition, it strengthens the relationship between mother and baby, and creates a superior future generation..$^{3,4}$ Therefore, to achieve this superior generation, the Surabaya City Government created the first 1000 days life assistance program for couples since October 2016. Studies explained that factors related to exclusive breastfeeding practices include age, educational level, financial and working status, antenatal care services, early feeding practices, babies' age, place of delivery and access to health services. Mothers aged over 30 years old reportedly improved breastfeeding practices compared to mothers aged less than 25 years old. Additionally, mothers living in rural areas were 4.54 times more likely to breastfeed (AOR 4.54; $95 \% \mathrm{CI}: 2.64,7.81, \mathrm{P}=0.001){ }^{5-}$ ${ }^{7}$ Despite multiple factors affected exclusive breastfeeding practice, traditional practices were still major barriers especially when it comes to introducing solid food too early. This study, therefore, aims to determine factors associated with exclusive breastfeeding.

\section{Design and Methods}

This is a cross-sectional study divided into 5 areas, namely, West, East, North, South and Central Surabaya. Data were obtained from the population of 1500 children above 6 months using the multistage random sampling method. However, the simple random sampling method was used in West and North Surabaya to obtain a total of 272 infants. Research data was based on the first 1000 days of life logbook reports of maternal age, education, family income, middle-upper arm nutritional status, body mass index, gestational age at delivery, frequency of antenatal care, place of delivery, methods and residence. The data collectors had a minimum qualification of bachelor degree in nutrition, midwives and public health graduates. To determine the relationship between independent and dependent variables, the data were analyzed using linear regression with $\alpha=0.05$.

Significance for public health

Overcoming barriers to exclusive breastfeeding helps to determine the effectiveness of successful breastfeeding program. This paper highlights factors influence exclusive breastfeeding, such as maternal age, educational level, family income, frequency of antenatal care, nutritional status before pregnancy, place and mode of delivery, and gestational age at delivery. 


\section{Results and Discussions}

Table 1 shows characteristics of respondents practicing nonexclusive breastfeeding (56.04\%), with the most participant being high school graduates $(63.00 \%)$, with an average age of 23.93 . Most participants' family incomes ranged from 4,100,000$6,000,000$ IDR, with a good ANC frequency, more than 9 times the visit. A total of $183(67 \%)$ participants had normal nutritional status based on MUAC and 164 (60.1\%) had BMI.

From Table 1, it was known that the majority of mothers have a good education. Furthermore, the age of the pregnant women was in accordance with the required time for marriage. Based on family income, some had income values, while the nutritional status before pregnancy was represented by Middle Upper Arm Circumference (MUAC) and Body Mass Index (BMI). This showed that there were still mothers with inadequate nutritional status for pregnancy. Approximately $6.6 \%$ of the babies were born prematurely due to the health condition of the mother.

Table 2 shows that family income is significantly related to the successful implementation of exclusive breastfeeding (0.047). Maternal nutritional status before pregnancy is represented by the Middle-Upper Arm Circumference and Body Mass Index, which are also significantly related to the successful implementation of exclusive breastfeeding ( 0.015 and 0.047$)$. Early breastfeeding initiation is significantly related to the successful implementation of exclusive breastfeeding (0.001).

Other variables such as mother's educational level, frequency of ANC, residence status, place of delivery, gestational age, delivery method and maternal age were not significantly related to its successful implementation.

The minimum wage for the City of Surabaya in March 2019 was $3,850,000 \mathrm{IDR} /$ month. However, most family's income is around regional minimum wage, although some are still lower. Exclusive breastfeeding is the right solution to provide the best and cheapest nutritional intake. Besides being healthy and nutritious for the baby, it is also very economical.

The pre-conception period is significant, especially for expectant mothers, because they have to prepare themselves during pregnancy, childbirth, and when breastfeeding the baby. Nutritional needs are higher during lactation compared to pregnancy. MUAC and BMI are depictions of past nutritional status and represent an adequate energy reserve. Conversely, in BMI, the maternal fat reserves are used as an additional requirement for producing milk. Babies born to mothers with poor nutritional status do not grow optimally, especially after 6 months. ${ }^{8}$ Previous study has shown that underfed pregnant women often experience failure in providing exclusive breastfeeding. ${ }^{9}$ Early breastfeeding initiation can provide stimulation to the production of oxytocin and prolactin, which are stimulated by skin contact when the baby sucks the mother's nipples in the first hour after delivery. ${ }^{10-12}$ The baby crawls to find her mother's nipples, giving rise to confidence: this increases the hormone prolactin and oxytocin. ${ }^{13,14}$ Early breastfeeding initiation can decrease infant mortality due to hypothermia, especially in preterm infant. ${ }^{15,16 .}$
Table 1. Characteristics of respondents.

\begin{tabular}{|c|c|c|}
\hline $\begin{array}{l}\text { Variables } \\
\text { Breastfeeding }\end{array}$ & $\mathrm{N}=273$ & $\%$ \\
\hline Exclusive & 120 & 43.96 \\
\hline Non-Exclusive & 153 & 56.04 \\
\hline \multicolumn{3}{|c|}{ Maternal educational level } \\
\hline Elementary School & 4 & 1.46 \\
\hline Junior High School & 8 & 2.93 \\
\hline Senior high school & 172 & 63.00 \\
\hline College & 85 & 31.14 \\
\hline Postgraduate & 4 & 1.46 \\
\hline \multicolumn{3}{|c|}{ Family income (IDR) } \\
\hline$<2,000,000$ & 20 & 7.33 \\
\hline $2,000,000-4,000,000$ & 96 & 35.16 \\
\hline$>4,000,000-6,000,000$ & 100 & 36.63 \\
\hline$>6,000,000-8,000,000$ & 42 & 15.38 \\
\hline$>8,000,000$ & 15 & 5.49 \\
\hline \multicolumn{3}{|c|}{ MUAC before pregnancy } \\
\hline Undernutrition & 90 & 33 \\
\hline Normal & 183 & 67 \\
\hline \multicolumn{3}{|c|}{ BMI before pregnancy } \\
\hline Underweight & 48 & 17.6 \\
\hline Normal & 164 & 60.1 \\
\hline Overweight & 49 & 17.9 \\
\hline Obesity & 12 & 4.4 \\
\hline \multicolumn{3}{|l|}{ Frequency of ANC } \\
\hline Normal & 201 & 73.6 \\
\hline High & 72 & 26.4 \\
\hline \multicolumn{3}{|c|}{ Gestational age at delivery } \\
\hline Premature & 18 & 6.6 \\
\hline Normal & 255 & 93.4 \\
\hline
\end{tabular}

Table 2. Linear regression test results

\begin{tabular}{lc} 
Variables & P value \\
Maternal educational level & 0.88 \\
Family income & 0.047 \\
\hline ANC frequency & 0.173 \\
Early breastfeeding initiation & 0.001 \\
\hline Resident status & 0.209 \\
Gestational age at delivery & 0.732 \\
\hline Place of delivery & 0.293 \\
Childbirth method & 0.371 \\
MUAC before pregnancy & 0.015 \\
Maternal age & 0.933 \\
\hline
\end{tabular}




\section{Conclusions}

In conclusion, nutritional status before pregnancy tends to benefit the family income, therefore, initiating early breastfeeding need to be improved for successful exclusive breastfeeding.

Correspondence: Sri Sumarmi, Department of Nutrition, Faculty of Public Health, Universitas Airlangga, Campus C Unair, Jln. Mulyosari, Surabaya, Indonesia.

Tel: +62315920948 , Fax: +62315924618

E-mail: msrisumarmi@gmail.com.

Key words: Nutritional status; family income; early breastfeeding initiation; exclusive breastfeeding.

Contributions: The authors contributed equally. Prof. Dr. Sri Sumarmi is supervisor in this study. Thanks to Professor Faruk Ahmed (Griffith University, Gold Coast, Australia) for giving advice in this article.

Conflict of interest: The authors declare no potential conflict of interest.

Funding: This research was supported by Universitas Airlangga.

Acknowledgments: The authors are grateful to the 4Th ISoPH committee for their kind support

Clinical trials: The study does not include any form of clinical trials.

Conference presentation: Part of this paper was presented at the $4^{\text {th }}$ International Symposium of Public Health, from October 31 to November 1, Griffith University, Gold Coast, Australia.

Received for publication: 6 March 2020.

Accepted for publication: 13 June 2020.

CCopyright: the Author(s), 2020

Licensee PAGEPress, Italy

Journal of Public Health Research 2020;9:1814

doi:10.4081/jphr.2020.1814

This work is licensed under a Creative Commons Attribution NonCommercial 4.0 License (CC BY-NC 4.0).

\section{References}

1. Kementerian Kesehatan Republik Indonesia. Rencana Strategis Kementerian Kesehatan Republik Indonesia Tahun 2015-2019. Pus Komun Publik 2014. Available from: http://www.depkes.go.id/article/view/1909/masalah-hiperten- si-di-indonesia.html. Accessed on: 6 December 2019.

2. Qoyyimah AU, Rohmawati W. Dampak pemberian ASI eksklusif terhadap kejadian sakit pada bayi usia 6-12 bulan di kabupaten Klaten. In 5th Urecol Proceeding 2017:1611-6. Available from: http://lpp.uad.ac.id/wp-content/uploads/2017/ 05/URECOL_ANNA-UQ_STIKES-MUKLA.pdf. Accessed on: 6 December 2019.

3. Suehara Y, Yazawa Y, Hitachi K, et al. Clear cell sarcoma arising from the chest wall: A case report. J Orthop Sci 2004;9:171-4.

4. Kent JC, Prime DK, Garbin CP. Principles for Maintaining or Increasing Breast Milk Production. JOGNN-J Obstet Gynecol Neonatal Nurs 2012;41:114-21.

5. Mundagowa PT, Chadambuka EM, Chimberengwa PT, et al. Determinants of exclusive breastfeeding among mothers of infants aged 6 to 12 months in Gwanda District, Zimbabwe. Int Breastfeed J. 2019;14:30.

6. Asemahagn MA. Determinants of exclusive breastfeeding practices among mothers in azezo district, northwest Ethiopia. Int Breastfeed J 2016;11:22.

7. Asfaw MM, Argaw MD, Kefene ZK. Factors associated with exclusive breastfeeding practices in Debre Berhan District, Central Ethiopia: a cross sectional community based study. Int Breastfeed J 2015;10:23.

8. Alam DS, van Raaij JMA, Hautvast JGAJ, et al. Energy stress during pregnancy and lactation: Consequences for maternal nutrition in rural Bangladesh. Eur J Clin Nutr 2003;57:151-6.

9. Syafiq SFA. Penyebab Keberhasilan dan Kegagalan Praktik Pemberian ASI Eksklusif. J Kesehat Masy Nasional 2010;4:120-31.

10. Karimi FZ, Sadeghi R, Maleki-Saghooni N, et al. The effect of mother-infant skin to skin contact on success and duration of first breastfeeding: A systematic review and meta-analysis. Taiwan J Obstet Gynecol 2019;58:1-9.

11. Ismiana A, Taufiqurrahman I, Siswishanto R. Pengaruh Cara Persalinan Terhadap Inisiasi Laktasi. J Kesehat Reproduksi 2018;1:214-21.

12. Mawaddah S. Hubungan Inisiasi Menyusu Dini Dengan Pemberian Asi Ekslusif Pada Bayi ( The Relationship of Early Breastfeeding Initiation with Exclusive Breastfeeding for Babies). J Info Kesehat 2018;16:214-25.

13. Clerke T, Hopwood N, Chavasse F, et al. Using professional expertise in partnership with families: A new model of capacity building. J Child Heal Care 2017;21:74-84.

14. Karakochuk CD, Whitfield KC, Green TJ, et al. The Biology Of The First 1000 Days. Florida: CRC Press; 2018.

15. Edmond KM, Zandoh C, Quigley MA, et al. Delayed breastfeeding initiation increases risk of neonatal mortality. Pediatrics 2006;117:e380-6

16. Hutagaol HS, Darwin E, Yantri E. Pengaruh Inisiasi Menyusu Dini (IMD) terhadap Suhu dan Kehilangan Panas pada Bayi Baru Lahir. J Kesehat Andalas 2014;3:332-8. 